\title{
Cretaceous and Tertiary extension throughout the Ross Sea, Antarctica
}

\author{
Robert C. Decesari, ${ }^{1,2}$ Douglas S. Wilson, ${ }^{1,3}$ Bruce P. Luyendyk, ${ }^{1}$ and Michael Faulkner ${ }^{4,5}$ \\ 'Dept. of Earth Science and Inst. for Crustal Studies, University of California, Santa Barbara, CA 93106, USA (rcdecesari@hotmail.com, \\ luyendyk@geol.ucsb.edu) \\ ${ }^{2}$ now at ExxonMobil Corporation, Houston, TX \\ ${ }^{3}$ Marine Science Inst., University of California, Santa Barbara, CA 93106, USA (dwilson@geol.ucsb.edu) \\ ${ }^{4}$ School of Earth Sciences, University of Leeds, U.K. \\ ${ }^{5}$ now at Shell Exploration \& Production International B.V., Netherlands (Michael.Faulkner@shell.com)
}

\begin{abstract}
Marine geophysical data from the deep sea adjacent to the Ross Sea, Antarctica suggest that $170 \mathrm{~km}$ of extension occurred between East and West Antarctica from 46 to $21 \mathrm{Ma}$. The Northern and Victoria Land Basins in the western Ross Sea adjacent to the Transantarctic Mountains accommodated $95 \mathrm{~km}$ of this extension. Several kilometers of Oligocene sediments are found in the Central Trough and Eastern Basin in the eastern Ross Sea. Subsidence modeling accounts for these accumulations with about $40 \mathrm{~km}$ of extension in each basin centered on $35 \mathrm{Ma}$; therefore Ross Sea-wide Tertiary extension was comparable to extension in the deep-sea system. The early Tertiary geometry was of one oceanic rift that branched into at least three rifts in the continental lithosphere. This pattern is likely due to the contrast of physical properties and thermal state between the two different lithospheres at the continent-ocean boundary.

Citation: Decesari, R.C., D.S. Wilson, B.P. Luyendyk, and M. Faulkner (2007), Cretaceous and Tertiary extension throughout the Ross Sea, Antarctica, in Antarctica: A Keystone in a Changing World - Online Proceedings of the 10th ISAES, edited by A.K. Cooper and C.R. Raymond et al., USGS Open-File Report 2007-1047, Short Research Paper 098, 6 p.; doi:10.3133/of2007-1047.srp098
\end{abstract}

\section{Introduction}

The Ross Sea overlies the extended lithosphere of the West Antarctic Rift System between East and West Antarctica. Extension in the rift is believed to have occurred in two main episodes; in the Cretaceous and in the Cenozoic(Davey and Brancolini, 1995). Cenozoic extension can be related to sea floor spreading on the Adare spreading system located northwest of the Ross Sea. Here 170-175 km of extension are thought to have occurred between 46 and $21 \mathrm{Ma}$ (Davey et al., 2006; Mueller et al., 2005). Extension was transferred across the continent-ocean boundary into the western Ross Sea to form or deepen basins in the margin. Cenozoic extension in the westernmost basin, the Victoria Land Basin, can be reconstructed to be about 95 $\mathrm{km}$, leaving a deficit of $75 \mathrm{~km}$ that must have occurred elsewhere (Davey et al., 2006). Others have suggested that extension was transferred eastward in the Ross Sea by right lateral shear (Salvini et al., 1997). The details of where the missing extension occurred and how this happened bear on rifting process at the continent-ocean transition. One possibility that we explore here is that other basins to the east of the Victoria Land basin also were extended during the Cenozoic.

The Ross Sea margin has four major basins, Northern Basin (NB), Victoria Land Basin (VLB), Central Trough (CT), and Eastern Basin (EB) (Fig. 1). Filling the basins are the Ross Sea seismic stratigraphic sequences RSS1 (putative Cretaceous) through RSS-8 (Pleistocene) separated by unconformities RSU6 ( $30 \mathrm{Ma})$ through RSU1 (Pleistocene) (ANTOSTRAT, 1995). We observe great thicknesses of Oligocene and younger strata in all basins and hypothesize that Cenozoic (Early Tertiary) extension and subsidence associated with Adare Basin spreading affected the VLB, and also the CT and EB, creating the necessary accommodation space needed for deposition. An alternative hypothesis limits Tertiary extension to only the VLB, suggesting the CT and EB were only affected by

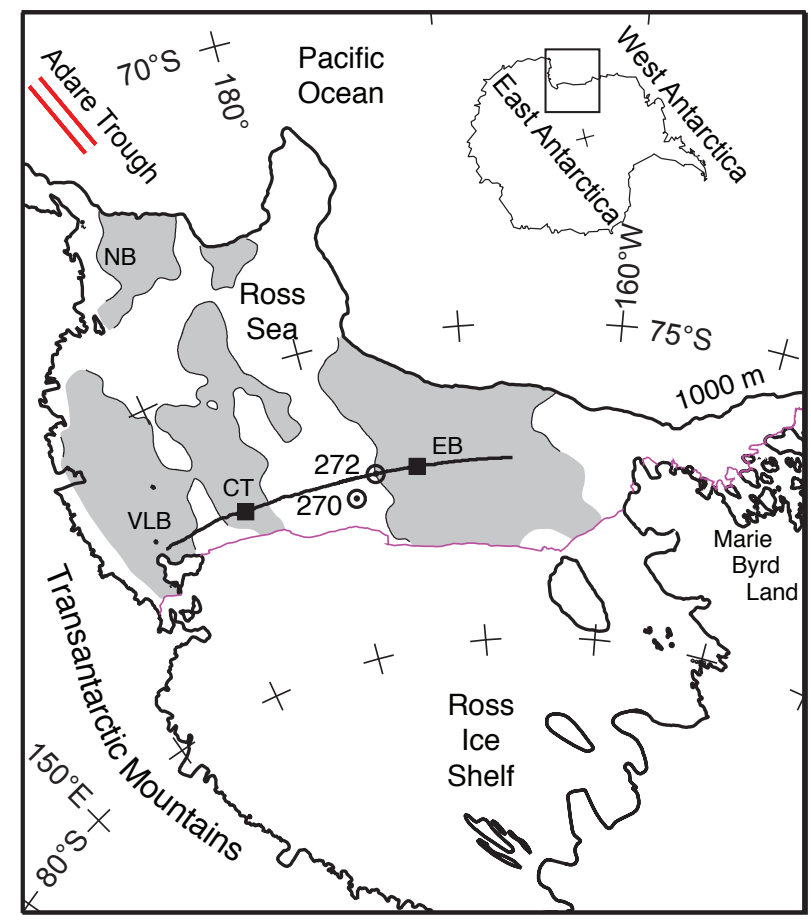

Figure 1. Location map for the Ross Sea area. Shading highlights sedimentary basins in Ross Sea, based on depth to basement deeper than $2.5 \mathrm{~km}$ [ANTOSTRAT, 1995]; NB, Northern Basin; VLB, Victoria Land Basin; CT, Central Trough; EB, Eastern Basin. Bold line shows coincident seismic profiles BGR-02 [ANTOSTRAT, 1995] and ACRUP2 [Trey et al., 1999]. Double circles show DSDP Sites 270 and 272 [Hayes et al., 1975]. Squares show locations analyzed for backstripping and 1-D subsidence.

Cretaceous extension (Karner et al., 2005). To test these hypotheses we use the backstripping method to determine the observed tectonic subsidence in the CT and EB and compare that to predicted tectonic subsidence curves using 
different combinations of lithosphere stretching factors. We find that for reasonable stretching, $80 \mathrm{~km}$ of total extension can be proposed for the CT and EB.

\section{Methods}

Backstripping analysis (Steckler and Watts, 1978) was done to convert observed basin stratigraphic thicknesses to basement subsidence history. A one dimensional (1-D) Airy isostatic subsidence history was produced for the $\mathrm{CT}$ and EB at two points along German seismic profile BGR02 (ANTOSTRAT, 1995). The VLB was not included in our analysis due to uncertainties in basement depth, unit thicknesses, and the unknown influence of Cenozoic volcanism. Corrections that were applied to the present stratigraphic thickness include decompaction (following Sclater and Christie (1980) using data from Hayes, Frakes et al. (1975); details in Decesari (2006)) of the sedimentary infill, isostatic compensation after decompaction, and paleobathymetric and eustatic sea level corrections. The result is the tectonic subsidence as a function of time. Global eustasy is accounted for using the curves of Miller et al. (2005). Due to limited available data, paleobathymetry was assumed as described later.

We predicted thermal subsidence using a model generalized from the instantaneous, pure-shear extension model of McKenzie (1978). Rather than his original Fourier-series solution for a single extension event, we used a finite-difference solution for temperature as a function of depth, which allows multiple extension events at different times. Following McKenzie, we used an initial lithosphere thickness of $125 \mathrm{~km}$, thermal expansion coefficient of 3.28 x $10^{-5}{ }^{\circ} \mathrm{C}^{-1}$, mantle temperature of $1330{ }^{\circ} \mathrm{C}$, and mantle density of $3.33 \mathrm{~g} \mathrm{~cm}^{-3}$. Subsidence for a single Cretaceous extension event and dual Cretaceous and Tertiary events were predicted for comparison against observations.

\section{Stratigraphic analysis}

Stratigraphic depths published for BGR-02 were based on stacking velocities (ANTOSTRAT, 1995). However, we consider depths computed from interval velocities to be more accurate. An interval velocity model for BGR-02 was computed from velocities for seismic profiles obtained on RVIB Nathaniel B. Palmer cruises NBP96-01 and NBP0301 that cross this line.

We reinterpreted unconformities RSU6-RSU3 in the $\mathrm{CT}$ and EB from the revised BGR-02 depth section. These unconformities separate the RSS-1 through RSS-6 seismic sequences (ANTOSTRAT, 1995) and are interpreted to have formed at or close to sea level (DeSantis et al., 1999). Thicknesses of RSS-2 (early Oligocene-early Miocene) through RSS-6, 7 \& 8 (late Miocene-Pliocene grouped as one unit) were calculated at the deepest locations of the basins (BGR-02 shot points 10450 in the CT and 4200 in the EB), ensuring analysis for the most extended crust. Acoustic basement depths in the basins could not be resolved from reflection seismic data and were obtained from gravity and seismic refraction modeling (Trey et al., 1999). Thickness of RSS-1 is then the difference between depths of the basement and RSU6. We assign an original depth of $100 \pm 50 \mathrm{~m}$ for RSU6 and $200 \pm 200 \mathrm{~m}$ for the younger unconformities.

\section{Results}

Both the CT and EB have 3 kilometers of Oligocene and younger sediments (post RSU6) that need to be explained by a subsidence history. The subsidence history prior to 30 Ma (putative age of RSU6) is poorly constrained due to the absence of dated unconformities older than early Oligocene. Since $95 \mathrm{Ma}$ (mid-point age we assume for Cretaceous rifting), more than $5.5 \mathrm{~km}$ of sediment accumulation has occurred in the Central Trough (Fig. 2a) and more than 7.5 $\mathrm{km}$ in the Eastern Basin (Fig. 2b).

Predicted thermal subsidence curves were fitted to tectonic subsidence curves for the $\mathrm{CT}$ and $\mathrm{EB}$ to determine the amount of Ross Sea lithosphere stretching $(\beta)$. A single Cretaceous extension event was considered first. Predicted tectonic subsidence curves for $\beta=2, \beta=4$, and $\beta=5$ were plotted against the observed tectonic subsidence (Fig. 2c). None of the observed subsidence curves fit the predicted Cretaceous-only extension model. This indicates that no amount of Cretaceous extension can account for the tectonic subsidence of the basement since $30 \mathrm{Ma}$, assuming that unconformity RSU6 formed at or near sea level.

Predicted two-stage Cretaceous (centered at $95 \mathrm{Ma}$ ) and Tertiary (centered at $35 \mathrm{Ma}$ ) extension can explain observed tectonic subsidence for the CT and EB. The observed tectonic subsidence of the $\mathrm{CT}$ and $\mathrm{EB}$ are bracketed by predicted subsidence curves using Cretaceous $\beta=2$, Tertiary $\beta=1.5$ and Cretaceous $\beta=2$, Tertiary $\beta=3$ (Fig. $2 d)$. Further refinement reveals that predicted subsidence resulting from Cretaceous $\beta=2$, Tertiary $\beta=2$ closely fits the EB observed total tectonic subsidence (Fig. 2d). The observed subsidence of the CT does not exactly fit a Cretaceous $\beta=2$, Tertiary $\beta=2$ curve, but does within the error limits. Both the $\mathrm{CT}$ and $\mathrm{EB}$ observed subsidence can also be explained by Cretaceous $\beta=1.5$, Tertiary $\beta=2.25$ and Cretaceous $\beta=1.5$, Tertiary $\beta=2.5$ (Fig. $2 \mathrm{~d}$ ). It is possible the CT may have a lower Cretaceous $\beta$ combined with a higher Tertiary $\beta$ that would produce similar results as the EB with Cretaceous and Tertiary $\beta=2$. Regardless, these results indicate that a period of significant Tertiary extension is needed to account for the observed subsidence of the CT and EB and the large thickness of Oligocene and younger sediments in them, if the unconformities formed at shallow depths.

\section{Discussion}

An alternative model for Ross Sea basin formation includes Cretaceous extension for NB, VLB, CT, and EB formation but limits Tertiary extension to the VLB and NB (Karner et al., 2005). The Cretaceous-only model for $\mathrm{CT}$ and $\mathrm{EB}$ necessitates that most thermal subsidence throughout the Ross Sea predates Oligocene sedimentation and requires that Cretaceous extension created deep paleobasins that persisted until Oligocene time (Karner et al., 2005).

For a single Cretaceous extension event to explain the subsidence history, Tertiary Ross Sea unconformities 


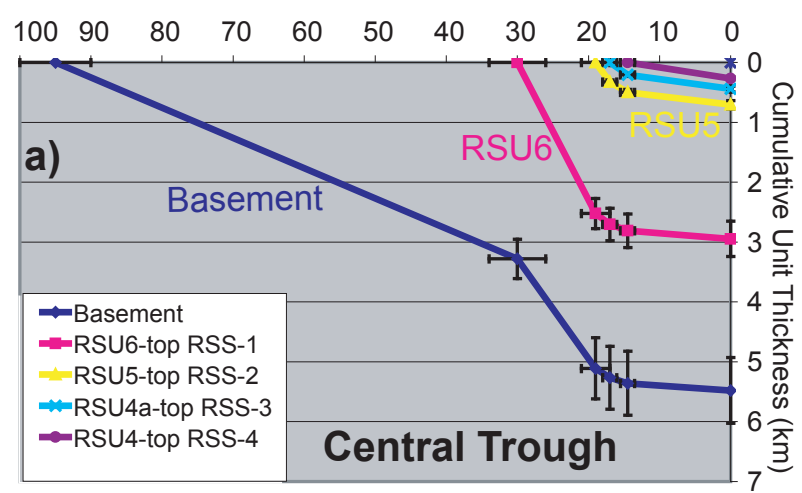

Age (Ma)

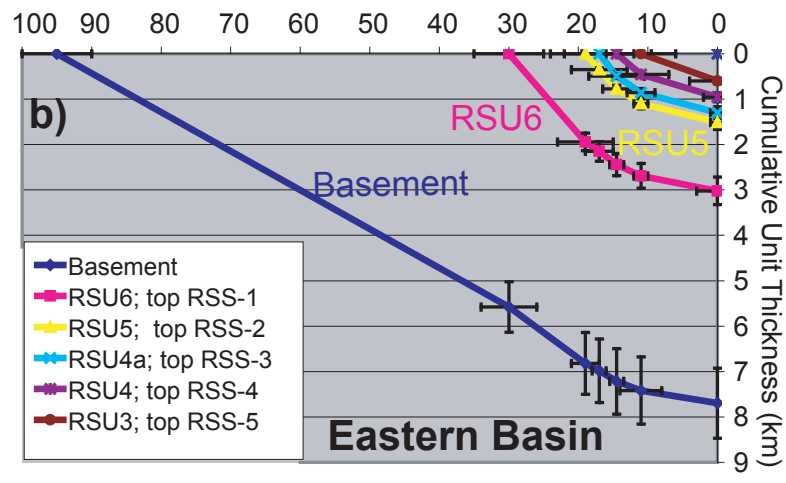

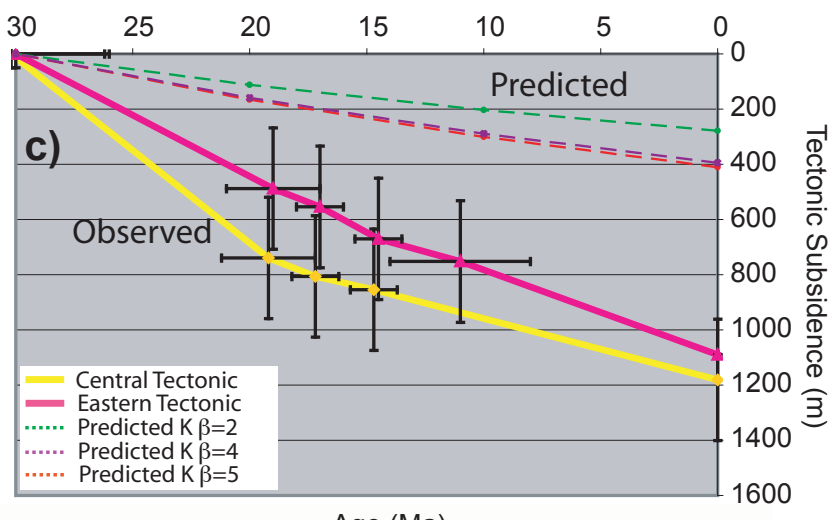

Age (Ma)

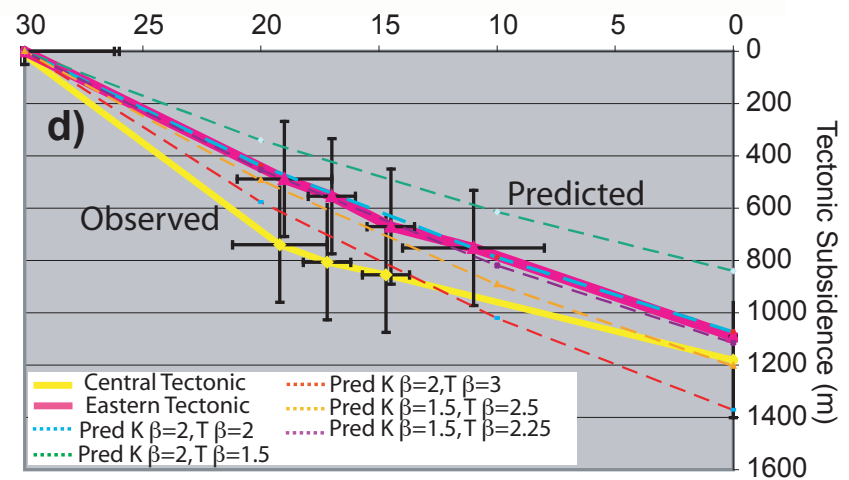

Figure 2. Decompacted sediment thickness histories and subsidence models. Left panels show thickness history corrected for compaction for Central Trough (a) and Eastern Basin (b) sites, with observed thickness at zero age. Right panels show observed tectonic subsidence for both sites (computed from thickness history, Airy load model, and estimated paleobathymetry), compared with subsidence predictions for models with extension at $95 \mathrm{Ma}(\mathrm{K})$ only (c) and at both $95 \mathrm{Ma}$ and $35 \mathrm{Ma}$ (T) (d). For Cretaceous-only extension, even high stretching factors of $\beta=4-5$ do not predict the computed subsidence (c). For the two-stage model, moderate stretching factors around 2 for both $\mathrm{K}$ and $\mathrm{T}$ events are consistent with the computed subsidence (d).

would have to have formed at depths of many hundreds of meters. The total tectonic subsidence of the EB was fitted to a Cretaceous $\beta=4$ predicted subsidence curve by increasing the paleo-water depth at each unconformity (Decesari, 2006). The results show that unconformity RSU6 would have to have formed at 900-m depth to fit this model.

How would the results for Cretaceous-only extension be different had flexural compensation been assumed as opposed to local Airy compensation? A local sediment load produces a broader area subsidence response in a flexural process than an Airy process. In a flexural response, the subsidence for a given sediment load is less than a local isostatic response. The backstripping analyses accounts for the observed sediment thickness by combining effects including tectonic subsidence, isostatic response and paleobathymetry. Therefore, less isostatic response at a basin center in a flexural compensation model requires deeper bathymetry to account for the observed thicknesses than a local compensation model. The paleobathymetry for RSU6 in flexural compensation with Cretaceousonly extension would be significantly deeper than $900 \mathrm{~m}$ found for the 1-D model. Alternatively, forming RSU6 at shallow depth in a flexural-compensation model would require more Tertiary extension than we have modeled. Properly accounting for flexural compensation may well be important for the Central Trough, which is fairly narrow and has a large positive gravity anomaly (e.g. Trey et al., 1999), but probably not for the wider Eastern Basin, where the low-amplitude gravity anomaly suggests that local compensation is a good approximation.

Unconformity RSU6 has been suggested to have formed as a $29-\mathrm{Ma}$ deepwater unconformity resulting from strong currents related to the opening of the Drake Passage (Hinz and Block, 1984). Deep water Oligocene unconformities are interpreted in the Indian Ocean and the western Pacific Ocean and may have resulted from erosive Oligocene Antarctic Bottom Water currents (Carter et al., 2004; Davies et al., 1975). Anderson and Bartek (1992) suggest subglacial erosion may have formed RSU6. However, DeSantis, et al. (1999) argue against this based on the improbability that a large-sized ice sheet was grounded on the seafloor at significant depth without leaving any signs of both erosion or deposition.

If unconformity RSU6 was cut at $900 \mathrm{~m}$ or more by grounded ice, significant erosion of RSS-1 would be expected. Rather, relatively parallel reflectors are seen above and below RSU6 (Decesari et al., 2004). This is characteristic of gentle sea floor slopes that are typical of shallow shelves. It seems unlikely that unconformity RSU6 formed at depths from glacial erosion. We favor the Ross 
Sea Tertiary unconformities originating at shallow water depths, formed from a combination of sea level changes and ice erosion. Therefore, we prefer a two-stage tectonic model starting with Cretaceous extension and followed by an early Tertiary event consistent forming unconformities in shallow water. The large degree of extension that we interpret requires a large initial crustal thickness. Prior to Cretaceous extension, the Ross Sea was probably an elevated region high above sea level (Fig. 3a) with thick continental crust $(\sim 50 \mathrm{~km})$. Cretaceous extension, possibly totaling several hundred kilometers, occurred between 105 and $80 \mathrm{Ma}$ (Siddoway et al., 2004). Modeled east-west extension centered on $\sim 95 \mathrm{Ma}$ at $\beta=\sim 2$ thinned the crust to $\sim 20-25$ km (Fig. 3b). Cretaceous sedimentary unit RSS-1 was deposited and deformed within basement grabens.

Modeled Tertiary extension centered around $\sim 35 \mathrm{Ma}$ correlates to the Adare Trough seafloor spreading event. Magnetic anomaly interpretation indicates about $180 \mathrm{~km}$ of E-W seafloor spreading occurred (Cande et al., 2000). However, the VLB is only 130 to $150 \mathrm{~km}$ wide, and Davey and De Santis (Davey and De Santis, 2006) interpreted only about $95 \mathrm{~km}$ of lithosphere extension in the VLB for Tertiary time. An excess of up to $85 \mathrm{~km}$ of Adare Trough extension must have been accommodated elsewhere. Cande and Stock (2006) propose either partitioning extension between the VLB and the Central Trough or the VLB accommodating all of the extension. Tertiary extension of $\sim 2: 1$ extended the Ross Sea further in localized areas corresponding to the proto-VLB (and NB), CT, and EB (Fig. 3c). We suggest the extension was partitioned over all of the Ross Sea basins, perhaps $100 \mathrm{~km}$ in VLB and $40 \mathrm{~km}$ each in CT and EB. Tertiary extension resulted in subsidence of RSS- 1 and RSU7 below sea level. No later than $30 \mathrm{Ma}$, unconformity RSU6 was cut near sea level.

Gravity data from the Ross Sea indicate the basins are characterized by positive anomalies, which can be used as a proxy for thinned continental crust (Hayes and Davey, 1975; Luyendyk et al., 2002), confirmed by seismic refraction experiments (Trey et al., 1999). We have complied a new gravity map of the Ross Sea and Ice Shelf from marine, ice surface, and satellite data ((modified after Luyendyk et al., 2002); Fig. 4), which shows a relationship between gravity highs and sedimentary basins. This map can therefore show the extent and location of Tertiary extension. Using the gravity proxy, Adare Trough extension splits into three branches in the Ross Sea continuing south under the ice shelf. The amplitude of the CT anomalies decreases to the south (Fig. 4), possibly indicating extension decreases to the south.

Davey et al. (2006) proposed that $95 \mathrm{~km}$ of Tertiary extension was accommodated in the VLB; our interpretation stipulates that an additional $\sim 80 \mathrm{~km}$ is distributed between the $\mathrm{CT}$ and $\mathrm{EB}$. Therefore, within uncertainties, this amount matches the $170 \mathrm{~km}$ proposed for the Adare spreading system. For these amounts of extension to agree, the relative motion pole must have been a moderate distance away from the Ross Sea. Davey et al. (2006) show a rotation pole for anomaly 18 in Marie Byrd Land; Cande et al. (2000)

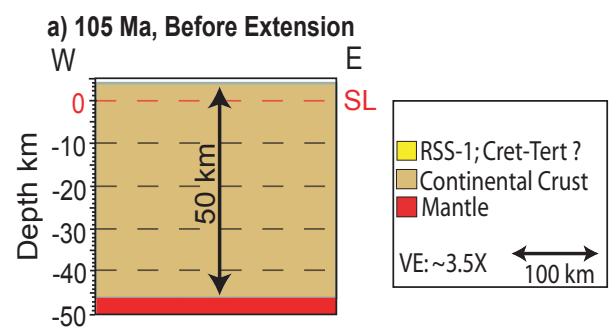

b) $85 \mathrm{Ma}$, After Cretaceous Extension
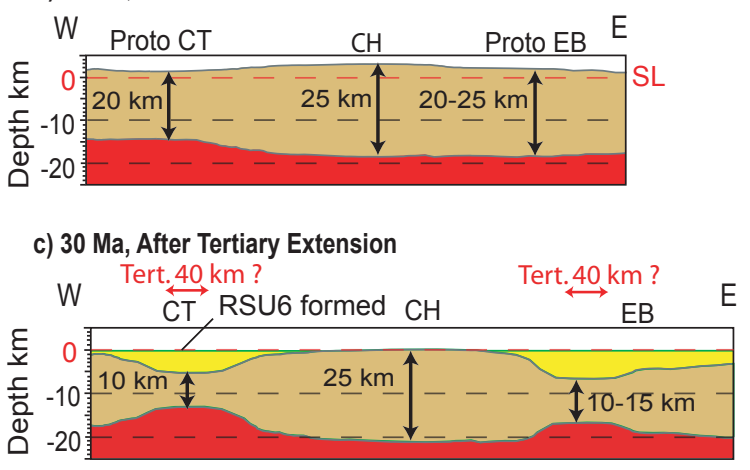

Figure 3. Model of central Ross Sea extension. a) 105 $\mathrm{Ma}$, before Cretaceous extension. The Ross Sea may have been an elevated region with crustal thickness of $\sim 50 \mathrm{~km}$. b) $85 \mathrm{Ma}$, after Cretaceous extension. Crust thins to 20-25 $\mathrm{km}$, graben formation accommodates a combined $>200$ $\mathrm{km}$ of E-W extension. c) $30 \mathrm{Ma}$, after Tertiary extension; localized crustal thinning of the proto-basins to $\sim 10 \mathrm{~km}$ thick and the formation of present-day Ross Sea basins. The Central High crust does not extend further and remains $25 \mathrm{~km}$ thick. The region is largely below sea level except for the Central High. Unconformity RSU6 is interpreted to form near sea level. SL= Sea Level.

show a pole for anomaly 13 located in the South Atlantic with a large uncertainty extending from the Weddell Sea to the northeast Atlantic. Because our analysis suggests that the Cenozoic extension amount is not discernibly different between the Adare system and the Ross Sea, the relative motion poles must have been farther away rather than closer.

Cande and Stock (2006) argue that because there are alignments of gravity and magnetic anomaly trends to the east of NB, all of the Adare extension must be restricted to the NB and the VLB to the south and none occurred to the east. We propose instead that extension in the NB decreases southward accommodated by clockwise rotation or distributed shear of the east flank of the NB (Figure $4 b)$.

\section{Conclusions}

The Ross Sea may cover foundered continental crust from the collapse of thick, elevated lithosphere since the Cretaceous (Fig. 3 Luyendyk et al., 2001). The Transantarctic Mountains (TAM) may be the preserved inland edge of the elevated region. Studinger et al. (2004) also interpret that West Antarctic structure and geologic history may be consistent with high plateau collapse. Bialas et al. (2005) propose a model of a thick lithosphere 

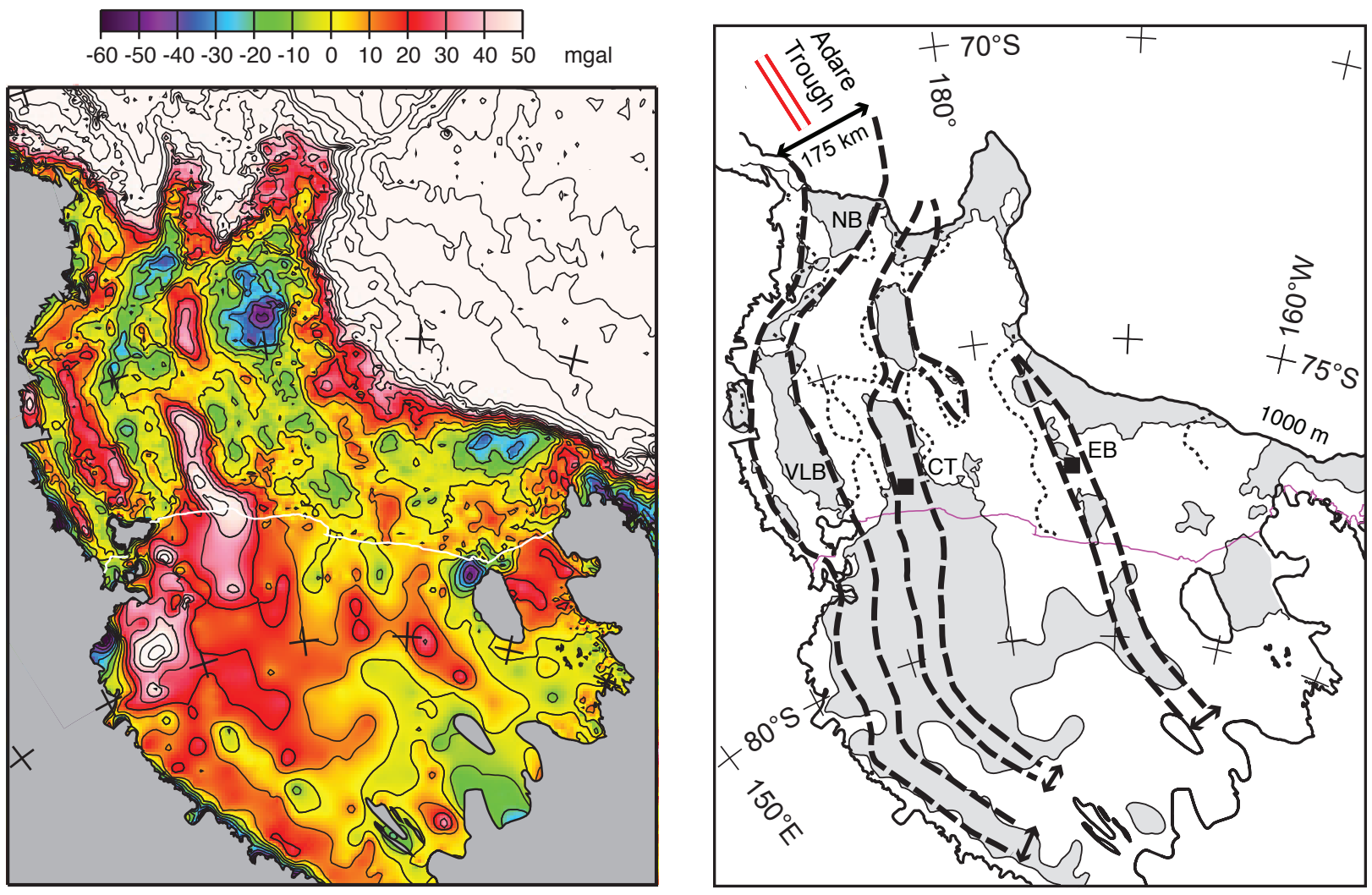

Figure 4. a) Bouguer gravity map of the Ross Sea and Ice Shelf (reduced at bed density $2300 \mathrm{Mg}$ m-3 estimated density of compacted surface sediments). Gravity data include ice shelf surface, [Greischar et al., 1992], satellite [McAdoo and Laxon, 1997], and new marine compilation [updated from Luyendyk et al., 2002]. Contour interval 10 mgal $<60 \mathrm{mgal} ; 20 \mathrm{mgal}>60 \mathrm{mgal}$. b) Interpretation with bold dashed lines outlining bands of highly extended crust interpreted from depth to basement and gravity anomalies. Shading shows Bouguer gravity anomaly greater than +10 mgal. Dotted lines in Ross Sea show $2.5-\mathrm{km}$ basement contour (Fig. 1). Positive gravity anomalies are located over the basins, indicating thinned crust. Arrow adjacent to Adare trough shows across-strike width of oceanic crust formed by the latest spreading episode; a similar amount of total extension must also be present to the south.

retaining significant elevation as adjacent lithosphere is extended and subsides.

Our analyses support extension and subsidence of Ross Sea lithosphere in two phases, the last of which occurred in three basins during early Tertiary time synchronous with Adare Trough spreading. A test for our hypotheses would include drilling and sampling Oligocene and older units in the Ross Sea.

We have presented a case where a rift in oceanic lithosphere crosses obliquely into continental lithosphere at the content-ocean boundary and shows a distributed region of strain. One or two oceanic rifts have branched into at least three rifts in the continental lithosphere. This pattern is likely due to the contrast of physical properties and thermal state between the two different lithospheres.

Acknowledgments. We acknowledge the assistance of the captain and crew, Raytheon staff, and the scientific party of the US RVIB Nathaniel B Palmer during expeditions 03-01 and 03-06. Chris Sorlien is thanked for his comments and assistance. Dan Herold and Matt Ralston of Parallel Geophysics Corp. proved valuable advice and help with seismic processing. Reviewed by Fred Davey, Joann Stock, and John Gamble. Students from UCSB and UNC participated in our field programs. Seismic Micro Corp. provided assistance with Kingdom Suite software. Supported by NSF grant OPP0088143. Contribution 0808 of the Institute for Crustal Studies.

\section{References}

Anderson, J. B., and L. R. Bartek (1992), Cenozoic glacial history of the Ross Sea revealed by intermediate resolution seismic reflection data combined with drill site information, in The Antarctic Paleoenvironment: A perspective on global change, edited by J. P. Kennett and D. A. Warnke, 56, pp. 231-263, Amer. Geophys. Union, Washington, D.C.

ANTOSTRAT (1995), Seismic Stratigraphic Atlas of the Ross Sea, in Geology and Seismic Stratigraphy of the Antarctic Margin, edited by A. K. Cooper, Barker, P. F., Brancolini, G., 68, p. 22 plates, American Geophysical Union, Washington, D.C.

Bialas, R. W., W. R. Buck, M. Studinger, and P. G. Fitzgerald (2005), Extending thickened continental crust: Implications for the Transantarctic Mountains and West Antarctic Rift System, EOS (American Geophysical Union Transactions), 86, 52, Fall Meet. Suppl., Abstract T43B-1407.

Cande, S. C., and J. M. Stock (2006), Constraints on the timing of extension in the Northern Basin, Ross Sea, in Antarctica, Contributions to Global Earth Science, edited by D. K. Futterer et al., pp. 319-326, Wurzburg, Germany.

Cande, S. C., J. M. Stock, D. Müller, and T. Ishihara (2000), Cenozoic Motion between East and West Antarctica, Nature, 404, 145-150.

Carter, L., R. M. Carter, and I. N. McCave (2004), Evolution of the sedimentary system beneath the deep Pacific inflow off eastern New Zealand, Marine Geology, 205, 1-4, 9-27

Davey, F. J., and G. Brancolini (1995), The Late Mesozoic and Cenozoic structural setting of the Ross Sea region, in Geology and Seismic Stratigraphy of the Antarctic Margin, edited by A. K. Cooper et al., 68, pp. 167-182, Amer. Geophys. Union, Washington, D.C.

Davey, F. J., S. C. Cande, and J. M. Stock (2006), Extension in the 
western Ross Sea region-links between Adare Basin and Victoria Land Basin, Geophysical Research Letters, 33, L20315, doi:10.1029/ 2006GL027383.

Davey, F. J., and L. De Santis (2006), Multi-phase Rifting Model for the Victoria Land Basin, Western Ross Sea, in Antarctica: Contributions to global Earth sciences, edited by D. K. Futterer et al., pp. 303-308, Springer-Verlag, Berlin.

Davies, T. A., O. E. Weser, B. P. Luyendyk, and R. B. Kidd (1975), Unconformities in the sediments of the Indian Ocean, Nature, 253, 1519.

Decesari, R. C. (2006), The Mesozoic and Cenozoic Depositional, Structural, and Tectonic Evolution of the Ross Sea, Antarctica, doctoral thesis, 232 pp, University of California, Santa Barbara.

Decesari, R. C., B. P. Luyendyk, L. R. Bartek, C. C. Sorlien, D. S. Wilson, J. B. Diebold, and S. E. Hopkins (2004), Ice shelf drill sites proposed to study Pre-Late Oligocene climate and tectonic history, Coulman High, Southwestern Ross Sea, Antarctica, EOS (American Geophysical Union Transactions), 85, 47, Fall Meet. Suppl., Abstract T11A-1244.

Decesari, R. C., D. S. Wilson, M. Faulkner, B. P. Luyendyk, and C. C. Sorlien (2005), A Model for Cretaceous and Tertiary Extension of the Ross Sea, Antarctica., EOS (American Geophysical Union Transactions), 86, 52, Fall Meet. Suppl., Abstract T53E-08.

DeSantis, L., S. Prato, G. Brancolini, M. Lovo, and L. Torelli (1999), The Eastern Ross Sea continental shelf during the Cenozoic: Implications for the West Antarctic ice sheet development, Global and Planetary Change, 23, 173-196.

Hayes, D. E., and F. J. Davey (1975), A geophysical study of the Ross Sea, Antarctica, in Initial Reports of the Deep Sea Drilling Project, Leg 28, edited by D. E. Hayes and L. A. Frakes, pp. 887-907, U.S. Government Printing Office, Washington, D.C.

Hayes, D. E., L. A. Frakes, and Shipboard_Scientific_Party (1975), Sites 270, 271, 272, in Initial Reports of the Deep Sea Drilling Project, Leg 28, edited by D. E. Hayes and L. A. Frakes, pp. 211-334.

Hinz, K., and M. Block (1984), Results of geophysical investigations in the Weddell Sea and in the Ross Sea, Antarctica, paper presented at 11 th World Petrol. Congress, Wiley, London.

Karner, G. D., M. Studinger, and R. E. Bell (2005), Gravity anomalies of sedimentary basins and their mechanical implications: Application to the Ross Sea basins, West Antarctica, Earth and Planetary Science Letters, 235, 577-596.

Luyendyk, B. P., C. C. Sorlien, D. S. Wilson, L. R. Bartek, and C. H. Siddoway (2001), Structural and tectonic evolution of the Ross Sea rift in the Cape Colbeck region, Eastern Ross Sea, Antarctica, Tectonics, 20, 933-958.

Luyendyk, B. P., D. S. Wilson, and R. Decesari (2002), New Maps of Gravity and Bedrock-Bathymetry of the Ross Sea Sector of Antarctica, EOS, Transactions of the American Geophysical Union, Fall Meeting Supplement, 83, 47, F1357.

McKenzie, D. (1978), Some remarks on the development of sedimentary basins, Earth and Planetary Science Letters, 40, 7, 25-32.

Mueller, R. D., S. C. Cande, J. M. Stock, and W. R. Keller (2005), Crustal structure and rift flank uplift of the Adare Trough, Antarctica, Geochemistry, Geophysics, Geosystems, 6, Q11010, doi:10.1029/ 2005 GC001027.

Salvini, F., G. Brancolini, M. Busetti, F. Storti, F. Mazzarini, and F. Coren (1997), Cenozoic geodynamics of the Ross sea region, Antarctica: Crustal extension, intraplate strike-slip faulting, and tectonic inheritance, Journal of Geophysical Research, 102, 24669-24696.

Sclater, J. G., and P. A. F. Christie (1980), Continental stretching: an explanation of the post mid-Cretaceous subsidence of the central North Sea basin, Journal of Geophysical Research, 85, 3711-3739.

Siddoway, C. S., S. L. Baldwin, P. G. Fitzgerald, C. M. Fanning, and B. P. Luyendyk (2004), Ross Sea mylonites and the timing of continental extension between East and West Antarctica, Geology, 32, 1, 57-60.

Steckler, M. S., and A. B. Watts (1978), Subsidence of the Atlantic-type continental margin off New York, Earth and Planetary Science Letters, $41,1,1-13$.

Studinger, M., R. E. Bell, W. R. Buck, G. Karner, and D. Blankenship (2004), Sub-ice geology inland of the Transantarctic Mountains in light of new aerogeophysical data, Earth and Planetary Science Letters, 220, 391-408.

Trey, H., A. K. Cooper, G. Pellis, B. Della Vedova, G. Cochrane, G. Brancolini, and J. Makris (1999), Transect across the West Antarctic rift system in the Ross Sea, Antarctica, Tectonophysics, 301, 61-74. 